\title{
ANALISIS PEMBUATAN DODOL BERBAHAN BAKU TEPUNG MELINJO DAN TEPUNG BERAS KETAN
}

\section{THE ANALYSIS OF MAKING DODOL OF MELINJO FLOUR AND GLUTINOUS RICE FLOUR}

\author{
Alyanti1), Patang2), Nurmila ${ }^{3)}$ \\ 1)Mahasiswa Program Studi Pendidikan Teknologi Pertanian FT UNM, \\ 2) dan 3)Dosen FT UNM \\ alyantiptp@yahoo.com
}

\begin{abstract}
ABSTRAK
Penelitian ini bertujuan untuk mengetahui pengaruh substitusi tepung melinjo terhadap kandungan protein, lemak, abu, air, dan karbohidrat pada dodol melinjo dan untuk mengetahui penerimaan panelis terhadap dodol melinjo berdasarkan hasil uji organoleptik.Rancangan yang digunakan dalam penelitian ini adalah Rancangan Acak Lengkap (RAL). Penelitian ini menggunakan formulasi yaitu perlakuan $\mathrm{K}$ (Tepung melinjo $0 \%$ dan tepung beras ketan $100 \%$ ), perlakuan $\mathrm{A}$ (Tepung melinjo $75 \%$ dan tepung beras ketan 25\%), perlakuan B (Tepung melinjo 60\% dan tepung beras ketan40\%), dan perlakuan C (Tepung melinjo50\% dan tepung beras ketan50 \%). Hasil penelitian menunjukkan bahwa uji proksimat terbaik dihasilkan pada perlakuan $\mathrm{C}$ dengan kosentrasi $50 \%$ tepung melinjo dan $50 \%$ tepung beras ketan.
\end{abstract}

Kata Kunci :,Tepung Melinjo, Tepung Beras Ketan, Dodol

\begin{abstract}
The study was aimed to determine the influence of melinjo flour substitution on the contents of protein, fat, ash, water, and carbohydrates in dodol melinjo and to determine the acceptance of the panelists on dodol melinjo based on the organoleptic test results. $A$ Completely Randomized Design (CRD) was applied in this study using formulation such as $K$ treatment (0\% melinjo flour and 100\% glutinous rice flour), A treatment (75\% melinjo flour and $25 \%$ glutinous rice flour), $B$ treatment (60\% melinjo flour and $40 \%$ glutinous rice flour), and $\mathrm{C}$ treatment (50\% melinjo flour and $50 \%$ glutinous rice flour). The result show that the best proximate test was resulted in $\mathrm{C}$ treatment with the same amount concentration between melinjo flour and glutinous rice flour.
\end{abstract}

Keywords: Melinjo Flour, Glutinous Rice Flour, Dodol

\section{PENDAHULUAN}

Melinjo merupakan salah satu komoditas pangan yang melimpah di
Indonesia.Melinjo merupakan tumbuhan tahunan yang dapat tumbuh mencapai 100 tahun lebih dan setiap panen mampu 
menghasilkan melinjo sebanyak 80 - 100 $\mathrm{kg}$.Tanaman melinjo banyak manfaatnya, hampir seluruh bagian tanaman melinjo dapat dimanfaatkan terdiri dari daun muda, bunga, dan kulit lunak biji. Semua makanan yang berasal dari tanaman melinjo mempunyai kandungan gizi yang cukup tinggi, kandungan gizi buah melinjo tua antara lain terdiri dari karbohidrat $(63,23 \%)$, lemak $(2,66 \%)$, protein $(17,39 \%)$ dan sejumlah vitamin (Yanti, 2002).

Berdasarkan kandungan gizi tanaman melinjo, berbagai jenis produk olahan melinjo dapat diolah dari buah melinjo tua, namun penggunaan melinjo masih belum populer di masyarakat, kerena hanya terbatas pada pembuatan emping melinjo dan sayur. Untuk lebih memanfaatkan melinjo pengolahan menjadi tepung merupakan salah satu alternatif untuk memperpanjang masa simpan melinjo sebagai produk setengah jadi (sebagai bahan baku). Di samping lebih tahan dalam penyimpanan, tepung melinjo dapat juga diolah menjadi berbagai jenis makanan sehingga dapat meningkatkan nilai tambah produk melinjo.

Pada prinsipnya proses pengolahan tepung melinjo adalah dengan pengeringan sampai kadar air biji mencapai 7 - 12\%. Tahap selanjutnya, biji melinjo kering (klatak) digiling sampai jadi tepung dan siap digunakan untuk berbagai jenis pengolahan kue kering (cookies). Penggunaan tepung melinjo dalam pengolahan kue-kue kering disamping dapat menambah cita rasa, juga menjadikan tampilan produk melinjo lebih menarik seperti dalam pembuatan dodol (Yanti, 2002). Selain menjadi kue kering tepung melinjo juga dapat dibuat menjadi produk lain seperti dodol.
Dodol merupakan salah satu jenis produk olahan hasil pertanian yang bersifat semi basah, berwarna putih sampai cokelat, dibuat dari campuran tepung ketan, gula, dan santan.Pengolahan dodol sudah dikenal masyarakat, prosesnya sederhana, murah dan banyak menyerap tenaga kerja (Soemaatmadja, 1997).Dodol terbuat dari daging buah matang yang dihancurkan, kemudian dimasak dengan penambahan gula dan bahan makanan lainnya atau tanpa penambahan bahan makanan lainnya. Sesuai dengan defenisi tersebut maka dalam pembuatan dodol buah-buahan diperbolehkan penambahan bahan lainnya seperti tepung ketan, tepung tapioka.Bahan-bahan yang ditambahkan harus sesuai dan tidak boleh lebih dari aturan yang berlaku (Satuhu et al., 2004). Oleh sebab itu penulis terinspirasi membuat dodol dari tepung melinjo karena selain mengandung kandungan gizi yang cukup tinggi juga mengandung karbohidrat, lemak, protein, mineral, dan vitamin dan dapat menjadi diversifikasi bahan makanan.

\section{TUJUAN PENELITIAN}

Penelitian ini bertujuan untuk mengetahui pengaruh substitusi tepung melinjo terhadap kandungan protein, lemak, abu, air, dan karbohidrat pada dodol melinjo dan untuk mengetahui penerimaan panelis terhadap dodol melinjo berdasarkan hasil uji organoleptik.

\section{METODE PENELITIAN}

Jenis penelitian ini adalah
penelitian eksperimen kuantitatif,
rancangan percobaan yang digunakan
dalam penelitian ini adalah Rancangan


Acak Lengkap (RAL) dengan 4 perlakuan dan 1 kontrol yang diulang sebanyak 3 kali ulangan. Adapun perlakuan dalam percobaan ini yaitu perlakuan $\mathrm{K}$ tepung melinjo $0 \%$ dan tepung beras ketan $100 \%$ sebagai kontrol, perlakuan A tepung melinjo $75 \%$ dan tepung beras ketan $25 \%$, perlakuan B tepung melinjo $60 \%$ dan tepung beras ketan $40 \%$, dan perlakuan C tepung melinjo $50 \%$ dan tepung beras ketan 50 $\%$.

Peralatan yang digunakan dalam penelitian ini yaitu; blender, timbangan analitik, kertas minyak/plastik, kompor, pengaduk kayu/spatula, pisau, sendok, talenan, wadah dan wajan.

Bahan yang digunakan yaitu; tepung beras ketan, tepung melinjo, gula merah dan santan kelapa.

Tahap pertama yaitu alur proses pembuatan melinjo menjadi tepung melinjo yaitu Sortasi dan pembersihan buah melinjo yang bertujuan menghilangkan kotoran yang melekat.Perebusan buah melinjo selama 3 - 4 jam sebanyak 2 liter. Pengupasan kulit luar dan kulit keras melinjolalu penencucian dan penjemuran, penjemuran dilakukan 3-4 hari dengan lama penjemuran 8 jam perhari. Pengupasan kulit tipis atau kulit ari melinjo selanjutnya penampian lalu di jemur. Kemudian disangrai dan dilakukan penampian. Kacang melinjo yang sudah jadi kemudian di blender sehingga menjadi tepung, dan dilakukan pengayakan hingga 80 mesh. Setelah itu dilakukan analisis proksimat dengan melakukan pengujian terhadap kadar protein, kadar lemak, kadar air, kadar abu, dan karbohidrat. Data analisis proksimat tiap perlakuan substitusi tepung diperoleh dari pengujian yang dilakukan di Politeknik Pertanian Negeri Pangkajene Kepulauan.
Tahap kedua yaitu alur proses pembuatan substitusi tepung melinjo menjadi dodol melinjo yaitu merebus santan kental hingga agak berminyak kemudian sisihkan. Merebus sebagian santan encer sampai agak mendidih dan masukkan gula merah hingga larut kemudian saring. Mencampur sebagian sisa santan encer dengan tepung beras ketan. Rebusan gula dididihkan dan memasukkan tepung melinjo dan tepung beras ketansubsitusi (0\%:100\%), (75\%:25\%), (60\%:40\%), (50\%:50\%). Memasukkan santan yang agak berminyak sambil diaduk terus sampai kental dan tidak melekat lagi di wajan selama 2 - 3 jam. Mendinginkan dodol di loyang yang sudah di alasi plastik putih dan tahap akhir yaitu pengemasan dimana dodol yang telah masak dibungkus dengan kertas minyak atau plastik dengan cara dodol yang telah matang diambil sebanyak 1 sendok dan diletakkan di atas kertas minyak atau plastik dan dibungkus sesuai selera.

$$
\text { Untuk mengetahui tingkat }
$$

kesukaan responden, jenis uji organoleptik yang digunakan yaitu metode uji kesukaan (hedonik) berdasarkan tingkat kesukaannya terhadap produk meliputi warna, aroma, tekstur dan rasa dengan skala penilaian 1-9 yaitu (1) amat sangat tidak suka, (2) sangat tidak suka, (3) tidak suka, (4) agak tidak suka, (5) netral, (6) agak suka, (7) suka, (8) sangat suka, (9) amat sangat suka, sebagai parameter penentuan suatu kesan dari suatu rangsangan yang ditimbulkan oleh produk. Data dikumpulkan dengan menggunakan angket (hedonic scale scoring).

Penelitian ini dilaksanakan di Laboratorium Pendidikan Teknologi Pertanian Fakultas Teknik Universitas Negeri Makassar. 
Data pada penelitian ini diperoleh dari hasil pengujian karakteristik organoleptik dengan menggunakan metode uji hedonik (kesukaan) yang dilakukan dengan menguji seberapa jauh tingkat kesukaan panelis terhadap karakteristik dodol melinjo yang meliputi tekstur, cita rasa, warna dan aroma. Panelis yang dilibatkan dalam pengujian ini yaitu panelis semi terlatih (semitrained panel) yang terdiri dari 25 orang dari kalangan mahasiswaData yang diperoleh dianalisis menggunakan analisis statistik sidik ragam ANOVA yang dilanjutkan dengan uji lanjut DMRT.

\section{HASIL DAN PEMBAHASAN}

\section{Kadar Air}

Pengujian kadar air dimaksudkan untuk mengetahui total air yang terkandung dalam dodol dengan penambahan tepung beras ketan dan tepung melinjo. Seperti yang diketahui bahwa kadar air $(20 \%)$ dalam suatu bahan pangan (dodol) sangat penting untuk mempertahankan daya simpan dari bahan pangan tersebut (Syarief et al., 1988). Pengujian kadar air dapat dilihat pada Gambar 1.

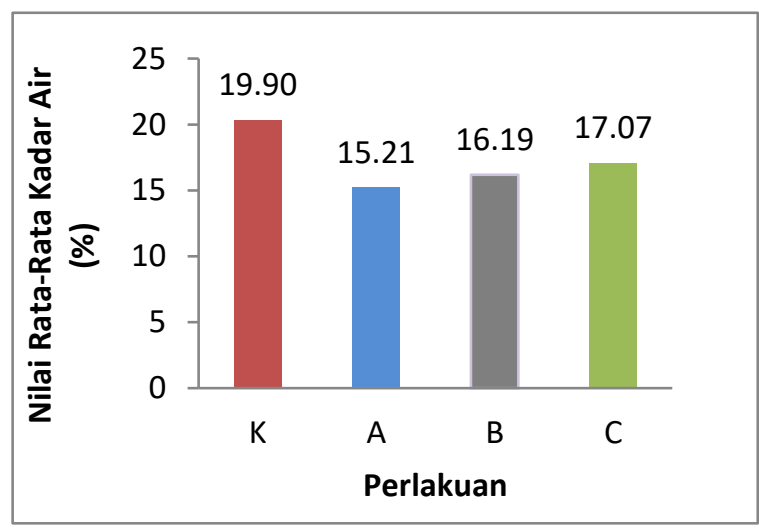

Gambar 1.

Hasil Uji Kadar Air Dodol Melinjo Dalam Penelitian
Ket :

$\mathrm{K}: 100 \%$ tepung beras ketan

A : $75 \%$ tepung melinjo dan $25 \%$ tepung beras ketan

B : $60 \%$ tepung melinjo dan $40 \%$ tepung beras ketan

C : $50 \%$ tepung melinjo dan $50 \%$ tepung beras ketan

\section{Berdasarkan Gambar 1}

menunjukkan hasil analisis kadar air pada dodol yang dilakukan menunjukkan bahwa kadar air pada masing-masing perlakuan berbeda-beda. Kadar air pada dodol berkisar antara $15.21 \%$ sampai $19.90 \%$. Kadar air dodol tertinggi terdapat pada perlakuan Kontrol (K) $0 \%$ tepung melinjo dan 100\% tepung beras ketan sebesar 19,90\%. Menyusul Perlakuan C (50\% tepung melinjo dan $50 \%$ tepung beras ketan) sebesar $17,07 \%$, perlakuan B $(60 \%$ tepung melinjo dan $40 \%$ tepung beras ketan) kadar air yang dihasilkan sebesar $16,19 \%$, dan jumlah kadar air terendah yaitu pada perlakuan A (75\% tepung melinjo dan $25 \%$ tepung beras ketan) yaitu sebesar $15.21 \%$.

Berdasarkan hasil penelitian terlihat bahwa kadar air menurun seiring dengan penambahan konsentrasi tepung melinjo yang meningkat Gambar 1, karena kadar air yang terdapat pada tepung melinjo lebih rendah dibandingkan tepung beras ketan masing-masing 6,32 dan 11,05. Tingginya kadar air pada perlakuan (K) diduga disebabkan oleh beras ketan yg bersifat pati yaitu suka dengan air. Hasil penelitian menunjukkan bahwa kadar air dodol melinjo memiliki nilai rata-rata yang berbeda. Hasil analisis ragam menunjukkan bahwa setiap perlakuan memberikan pengaruh nyata terhadap perubahan kadar air dodol melinjo. 
Menurut Haryadi (2006), tepung beras ketan pada pemanasan dengan keberadaan cukup banyak air, menyebabkan pati yang terkandung dalam tepung akan menyerap air dan membentuk pasta yang kental dan pada saat dingin membentuk massa yang kenyal, lenting dan liat.

\section{Kadar Abu}

Pengujian kadar abu dimaksudkan untuk mengetahui total abu yang terkandung dalam dodol dengan penambahan tepung beras ketan dan tepung melinjo dapat dilihat pada Gambar 2

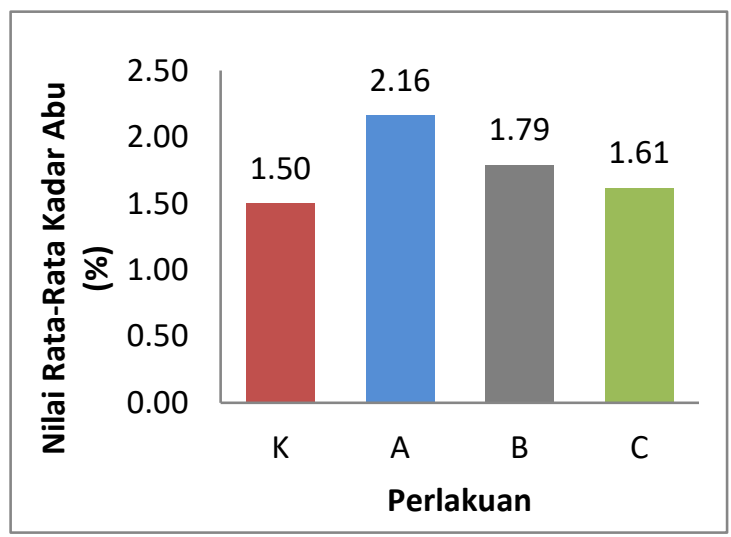

Gambar 2.

Hasil Uji Kadar Abu Dodol Melinjo Dalam Penelitian

Ket :

$\mathrm{K}: 100 \%$ tepung beras ketan

A : $75 \%$ tepung melinjo dan $25 \%$ tepung beras ketan

B : $60 \%$ tepung melinjo dan $40 \%$ tepung beras ketan

C : $50 \%$ tepung melinjo dan $50 \%$ tepung beras ketan

Berdasarkan Gambar 2 menunjukkan hasil analisis kadar abu pada dodol yang dilakukan menunjukkan bahwa kadar abu pada masing-masing perlakuan berbeda-beda. Kadar abu pada dodol berkisar antara 1,50\% sampai $2,16 \%$. Kadar abu dodol tertinggi terdapat pada perlakuan A (tepung melinjo $75 \%$ dan $25 \%$ tepung beras ketan) sebesar 2.16\%, menyusul perlakuan B (tepung melinjo $60 \%$ dan tepung beras ketan $40 \%$ ) yaitu sebesar $1,79 \%$. Sedangkan pada perlakuan $C$ (50\% tepung melinjo dan $50 \%$ tepung beras ketan) kadar air yang dihasilkan sebesar 1,61\% dan jumlah kadar air terendah yaitu pada perlakuan $\mathrm{K}$ (penambahan $0 \%$ tepung melinjo dan $100 \%$ beras ketan) yaitu sebesar $1,50 \%$. Berdasarkan Gambar 2 menunjukkan hasil analisis kadar abu pada dodol melinjo yang dilakukan menunjukkan bahwa kadar abu pada masing-masing perlakuan berbeda-beda. Tingginya kadar abu pada perlakuan $\mathrm{A}$ diduga disebabkan oleh penambahan berat tepung melinjo 75\%, karena kadar abu yang terdapat pada tepung melinjo yaitu $1,76 \%$ dibandingkan kadar abu yang terdapat pada tepung beras ketan yaitu $0,29 \%$ dengan demikian semakin tingginya kosentrasi penambahan tepung melinjo akan berpengaruh semakin meningkatnya kadar abu pada dodol. Hal ini tidak sesuai dengan syarat mutu dodol menurut SNI No 01-2986-1992 dimana nilai maksimal abu dodol yaitu maksimal $1,5 \%$.

\section{Kadar Lemak}

Minyak atau santan perlu ditambahkan dalam makanan seperti pada pembuatan dodol karena mengandung energi yang tinggi.Lemak atau minyak dapat memberi rasa gurih dan makanan menjadi lebih lunak dan mudah ditelan.Jenis minyak yang umum digunakan yaitu minyak kelapa, santan, minyak goreng, minyak kacang, dan minyak nabati lainnya (Krisnatuti et al, 
2004). Hasil uji kadar lemak dodol dapat dilihat pada Gambar 3.

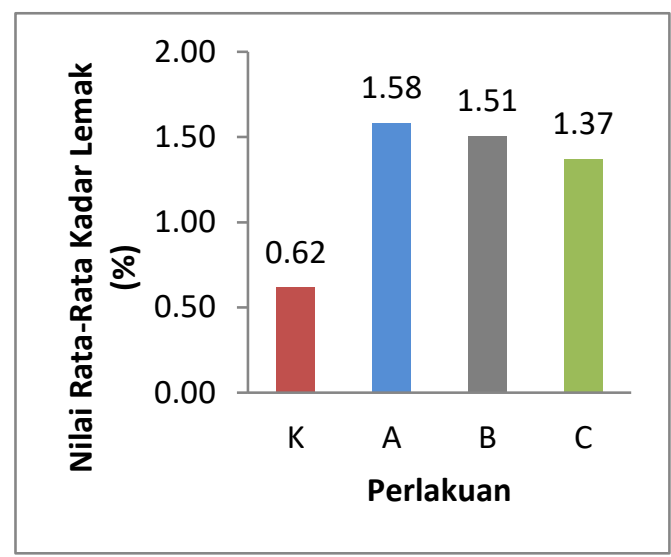

Gambar 3.

Hasil Uji Kadar Lemak Dodol Melinjo

Dalam Penelitian

Ket :

$\mathrm{K}: 100 \%$ tepung beras ketan

A : $75 \%$ tepung melinjo dan $25 \%$ tepung beras ketan

B : $60 \%$ tepung melinjo dan $40 \%$ tepung beras ketan

C : $50 \%$ tepung melinjo dan $50 \%$ tepung beras ketan

Berdasarkan Gambar 3 menujukkan hasil analisis kadar lemak pada dodol berkisar antara 0,62\% sampai $1,58 \%$. Kadarlemak tertinggi terdapat pada perlakuan penambahan $\mathrm{A}$ (75\% tepung melinjo dan $25 \%$ tepung beras ketan) yaitu sebesar $1,58 \%$, menyusul perlakuan B $(60 \%$ tepung melinjo dan $40 \%$ tepung beras ketan) yaitu sebesar $1,51 \%$. Perlakuan $C$ (tepung melinjo $50 \%$ dan tepung beras ketan $50 \%$,) sebesar $1,37 \%$ dan kadar lemak terendah yaitu perlakuan $\mathrm{K}(0 \%$ tepung melinjo dan $100 \%$ tepung beras ketan) yaitu sebesar 0,62\%.

Berdasarkan Gambar 3 Hasil

uji proksimat, kadar lemak tepung melinjo lebihtinggi dibanding kadar lemak tepung beras ketan ini berarti bahwa makin banyak tepung melinjo yang digunakan pada pembuatan dodol maka makin tinggi kadar lemak dari dodol terebut. Kadar lemak yang tinggi dalam dodol dapat menyebabkan semakin cepat terjadi proses ketengikan. Hal ini sesuai dengan pendapat Hardiansyah (2000), bahwa lemak terdapat hampir pada semua bahan pangan dengan kandungan yang berbeda - beda.kadar lemak minimal adalah 3\%. Kadar lemak yang tinggi dalam dodol dapat menyebabkan semakin cepat terjadi proses ketengikan. Hal ini sesuai dengan pendapat Hardiansyah (2000), bahwa lemak terdapat hampir pada semua bahan pangan dengan kandungan yang berbeda-beda.

\section{Kadar Protein}

Analisa kadar protein dimaksudkan untuk mengetahui kadar protein dalam dodol. Hasil analisa kadar protein dapat dilihat pada Gambar 4 berikut :

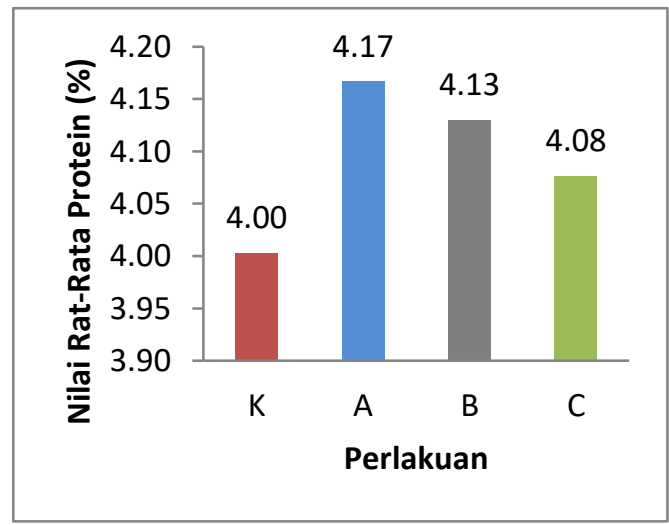

Gambar 4.

Hasil Uji Kadar Protein Dodol Melinjo Dalam Penelitian 
Ket :

$\mathrm{K}: 100 \%$ tepung beras ketan

A : $75 \%$ tepung melinjo dan $25 \%$ tepung beras ketan

B : $60 \%$ tepung melinjo dan $40 \%$ tepung beras ketan

C : $50 \%$ tepung melinjo dan $50 \%$ tepung beras ketan

Berdasarkan Gambar 4 kadar protein tertinggi terdapat pada perlakuan A (tepung melinjo $75 \%$ dan tepung beras ketan $25 \%$ ) sebesar $4,17 \%$, menyusul . perlakuan B (tepung melinjo 60\% dan tepung beras ketan 40\%) sebesar $4,13 \%$, pada perlakuan C (tepung melinjo $60 \%$ dan tepung beras ketan $40 \%$ ) sebesar $4,08 \%$, sedangkan hasil analisa terendah terdapat pada perlakuan $\mathrm{K}$ (tepung melinjo $50 \%$ dan tepung beras ketan 50\%) sebesar $4,00 \%$.

Berdasarkan Gambar 4 Kadar protein yang relative tinggi pada dodol ini diduga disebabkan oleh tepung melinjo sebagai bahan tambahan pada dodol yang memiliki kandungan protein yang sangat tinggi yaitu $12.86 \%$, juga karena adanya kontribusi dari kadar protein tepung beras ketan. Kadar protein dari tepung beras ketan adalah $6.61 \%$. Hal ini disebabkan karena adanya pengaruh dari suhu yang digunakan selama pengolahan yang dapat menyebabkan denaturasi protein.Menurut (Matias, 2010) Protein pangan terdenaturasi jika dipanaskan pada suhu moderat $60-900 \mathrm{C}$ selama satu jam atau lebih.Denaturasi adalah perubahan struktur protein dimana pada keadaan terdenaturasi penuh hanya struktur primer saja yang tersisa.Protein tidak lagi memiliki struktur sekunder, tersier dan kuartener.

Dodol ini tergolong layak atau sesuai dengan syarat mutu dodol menurut SNI No 01-2986-1992 dimana nilai rata-rata mainimal dodol $3 \%$.

\section{Kadar Karbohidrat}

Analisis kadar karbohidrat dilakukan untuk mengetahui kandungan karbohidrat yang terdapat dalam dodol. Dapat dilihat pada Gambar 5.

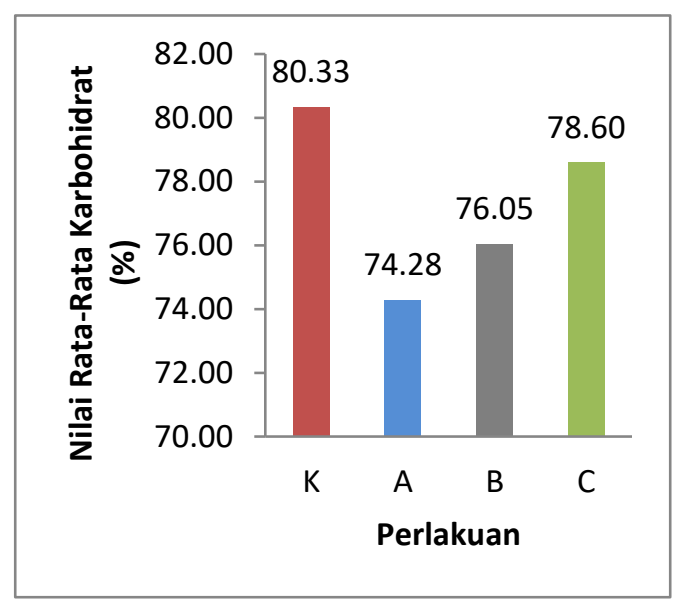

Gambar 5.

Hasil Uji Karbohidrat Dodol Melinjo Dalam Penelitian

Ket :

K : $100 \%$ tepung beras ketan

A : $75 \%$ tepung melinjo dan $25 \%$ tepung beras ketan

B : $60 \%$ tepung melinjo dan $40 \%$ tepung beras ketan

C : $50 \%$ tepung melinjo dan $50 \%$ tepung beras ketan

Berdasarkan Gambar 5 dimana tepung melinjo dan dengan konsentrasi tepung beras ketan memiliki kadar karbohidrat yang berbeda-beda. Dimana kadar karbohidrat tertinggi terdapat pada perlakuan K $(0 \%$ tepung melinjo dan $100 \%$ tepung beras ketan) yaitu $80,33 \%$ , menyusul perlakuan C (50\% tepung melinjo dan $50 \%$ tepung beras ketan) sebesar $78,60 \%$, perlakuan B $(60 \%$ tepung melinjo dan $40 \%$ tepung beras ketan) sebesar $76,05 \%$ dan sedangkan yang terendah terdapat pada perlakuan 
A (0\% tepung melinjo dan $50 \%$ tepung beras ketan) yaitu $74,28 \%$.

Beberapa zat yang termasuk golongan karbohidrat adalah gula, dekstrin, pati, selulosa, hemiselulosa, pectin, gum dan beberapa karbohidrat lainnya (Winarno 2008). Kadar karbohidrat diperoleh dengan cara by difference yaitu pengurangan $100 \%$ dengan jumlah kadar protein, kadar air, kadar lemak dan kadar abu.

Berdasarkan Gambar 5 dimana tepung melinjo dan dengan konsentrasi tepung beras ketan memiliki kadar karbohidrat yang berbeda-beda. Tingginya kadar karbohidrat pada perlakuan $\mathrm{K}$ diduga disebabkan karena beras ketan yang memiliki kandungan karbohidrat yang tinggi. Karbohidrat berfungsi sebagai protein sparer karena keperluan energy tubuh telah dipenuhi oleh karbohidrat sehingga protein akan digunakan untik keperluan fungsi utamanya sebagai zat pembangun, tidak perlu dioksidasi menjadi energi (Tejasari, 2005).

\section{Warna}

Warna pada makanan dapat disebabkan oleh beberapa sumber diantaranya adalah pigmen, pengaruh panas pada gula (caramel), adanya reaksi antara gula dan asam amino (reaksi Maillard), dan adanya pencampuran bahan lain (Winarno, 2004). Secara visual, faktor warna sangat menentukan mutu.Hasil uji orgonoleptik warna dodol dapata dilihat pada Gambar 6.

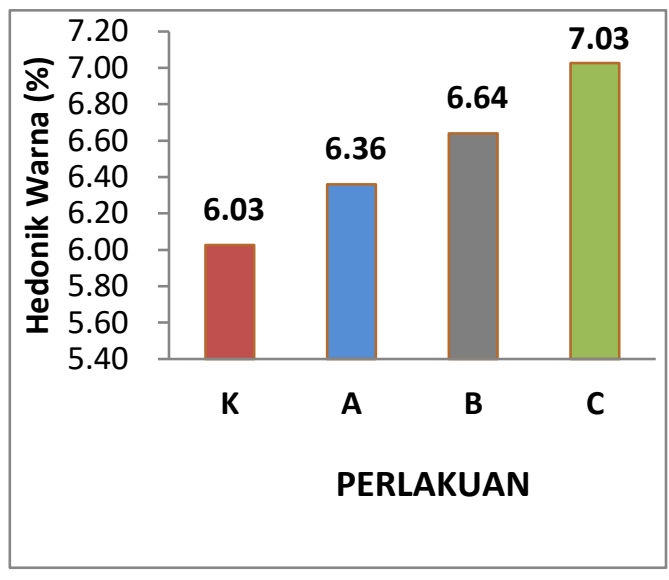

Gambar 6.

Hasil Uji Orgonoleptik Warna Dodol Dalam Penelitian.

Ket :

$\mathrm{K}: 100 \%$ tepung beras ketan

A : $75 \%$ tepung melinjo dan $25 \%$ tepung beras ketan

B : $60 \%$ tepung melinjo dan $40 \%$ tepung beras ketan

C : $50 \%$ tepung melinjo dan $50 \%$ tepung beras ketan

Berdasarka Gambar 6 menunjukkan hasil pengujian sensorik terhadap warna pada dodol yang dilakukan menunjukkan bahwa produk dapat diterima oleh panelis. Penilaian terhadap warna yang tertinggi terdapat pada perlakuan C (50\% tepung melinjo dan $50 \%$ beras ketan) yaitu sebesar $7,03 \%$ (suka). Menyusul pada perlakuanB $(60 \%$ tepung melinjo dan $40 \%$ beras ketan) yaitu dengan nilai $6,64 \%$ (agak suka) dan perlakuan A (75\% tepung melinjo dan $25 \%$ gula beras ketan) yaitu sebesar 6,36\% (agak suka) dan yang terendah adalah perlakuan $\mathrm{K}$ (0\% tepung melinjo dan 100\% tepung beras ketan) sebesar $6.03 \%$.

Pada umumnya warna yang terdapat pada dodol yaitu coklat, coklat gelap, coklat agak gelap.Berdasarkan hasil penelitian menunjukkan bahwa 
warna yang disukai oleh panelis yaitu warna cokelat gelap yaitu pada perlakuan C (50\% tepung beras ketan dan $50 \%$ tepung melinjo).Hal ini disebabkan karena penambahan tepung beras dan tepung melinjo sehingga warna yang dihasilkan berbeda pula.

\section{Rasa}

\section{Berdasarkan rasa merupakan salah satu faktor dalam pengujian organoleptik.Rasa lebih banyak} melibatkan indera lidah.Cita rasa dari bahan pangan sesungguhnya terdiri dari tiga komponen yaitu: bau, rasa, dan ransangan mulut (Rampengan et al.,1985).Hasil uji orgonoleptik rasa dodol dapat dilihat pada Gambar 7.

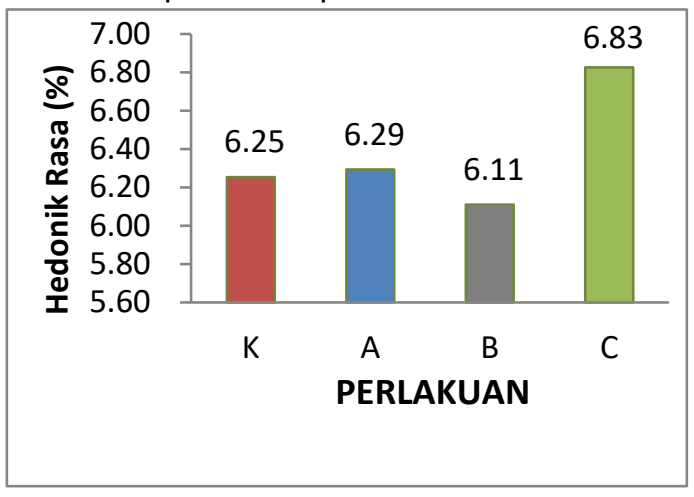

Gambar 7.

Hasil Uji Orgonoleptik Rasa Dodol Dalam Penelitian.

Ket :

$\mathrm{K}: 100 \%$ tepung beras ketan

A : $75 \%$ tepung melinjo dan $25 \%$ tepung beras ketan

B : $60 \%$ tepung melinjo dan $40 \%$ tepung beras ketan

C : $50 \%$ tepung melinjo dan $50 \%$ tepung beras ketan

Berdasarkan Gambar 7

menunjukan hasil penilaian terhadap rasa yang tertinggi terdapat pada perlakuan C (50\% tepung melinjo dan $50 \%$ tepung beras ketan) yaitu sebesar
6,83 (agak suka). Menyusul perlakuan A (75\% tepung melinjo dan 25\% tepung beras ketan) sebesar 6,29\% (agak suka), dan perlakuan $\mathrm{K}(0 \%$ tepung melinjo dan $100 \%$ tepung beras ketan) sebesar $6,25 \%$ (agak suka), selanjutnya penilaian terendah yaitu perlakuan B $(60 \%$ tepung melinjo dan $40 \%$ tepung beras ketan) sebesar $6,11 \%$ (agak suka).

Berdasarkan hasil penelitian menunjukkan bahwa rasa yang disukai oleh panelis penggunaan tepung melinjo setara dengan tepung beras ketan yaitu pada perlakuan C (50\% tepung beras ketan dan 50\% tepung melinjo) karena rasa yang dihsilkan tidak terlalu pahit dan masih memiliki rasa khas dodol. Hasil pengujian sensorik terhadap rasa pada dodol yang dilakukan menunjukkan bahwa produk dapat diterima oleh panelis.

\section{Aroma}

Aroma merupakan salah satu factor penting yang mempengeruhi penerimaan suatu produk olahan seperti dodol. Dodol yang baik akan mengeluarkan aroma khas dodol dari pemasakan santan, beras ketan, gula merah serta bahan subtitusi berupa buah melinjo.Dapat dilihat pada Gambar 8.

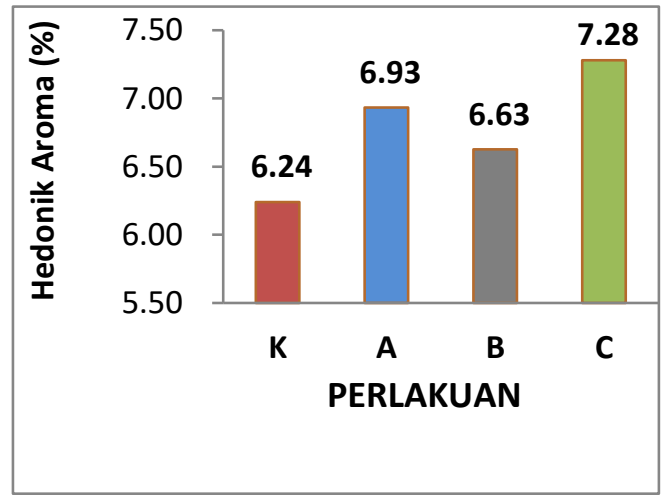

Gambar 8.

Hasil Uji Orgonoleptik Aroma Dodol Dalam Penelitian. 
Ket :

$\mathrm{K}: 100 \%$ tepung beras ketan

A : $75 \%$ tepung melinjo dan $25 \%$ tepung beras ketan

B : $60 \%$ tepung melinjo dan $40 \%$ tepung beras ketan

C : $50 \%$ tepung melinjo dan $50 \%$ tepung beras ketan

Berdasarka Gambar 8 hasil pengujian sensorik terhadap aroma pada dodol yang dihasilkan menunjukkan bahwa produk dapat diterima oleh panelis dengan persentase dari setiap perlakuan yaitu agak suka. Penilaian terhadap aroma yang tertinggi terdapat pada perlakuan C (50\% tepung melinjo dan $50 \%$ tepung beras ketan) yaitu 7,28 (suka), menyusul perlakuan A $(75 \%$ tepung melinjo dan $25 \%$ tepung beras ketan) yaitu 6,93 (agak suka), sedangkan pada perlakuan B $(60 \%$ tepung melinjo dan $40 \%$ tepung beras ketan) yaitu 6,63 (agak suka) dan penilaian terendah pada perlakuan $\mathrm{K}$ (6,24\% pada perlakuan $0 \%$ tepung melinjo dan $100 \%$ tepung beras ketan ) sebesar6,24\% (agak suka).

Berdasarkan Gambar 8 hasil pengujian sensorik terhadap aroma pada dodol yang dihasilkan menunjukkan bahwa produk dapat diterima oleh panelis dengan persentase dari setiap perlakuan yaitu agak suka. Menurut Winarno (2008), aroma yang paling diminati oleh panelis yaitu pada perlakuan C (50\% tepung beras ketan dan 50\% tepung melinjo) dimana aroma yang dihasilkan aroma khas dodol dengan tambahan aroma melinjonya.

Aroma yang diinginkan dodol melinjo berdasarkan SNI yaitu normal.Skala normal yaitu apabila produk berbau khas dodol dengan aroma santan, gula merah dan tepung ketan serta aroma khas bahan tambah yaitu tepung melinjo.

\section{Tektur}

Salah satu cara penentuan tekstur suatu dodol adalah memberikan beban terhadap dodol tersebut misalnya dengan pemeriksaan bekas atau tekanan jari. Hasil uji orgonoleptik tekstur

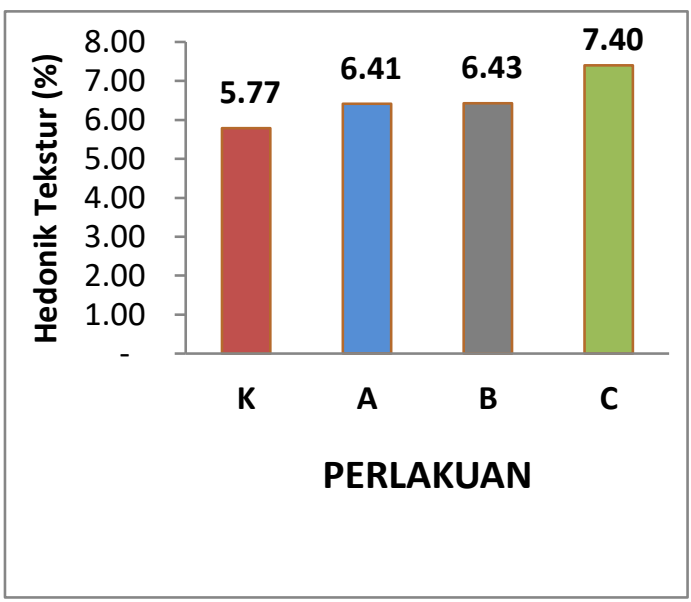

dodol dapat dilihat pada Gambar 9.

Gambar 9.

Hasil Uji Orgonoleptik Tekstur Dodol

Dalam Penelitian

Ket :

$\mathrm{K}: 100 \%$ tepung beras ketan

A : $75 \%$ tepung melinjo dan $25 \%$ tepung beras ketan

B : $60 \%$ tepung melinjo dan $40 \%$ tepung beras ketan

C : $50 \%$ tepung melinjo dan $50 \%$ tepung beras ketan

Berdasarkan Gambar 9 hasil pengujian sensorik terhadap tekstur dodol dapat diterima oleh panelis. Penilaian terhadap tekstur yang tertinggi terdapat pada perlakuan C (50\% tepung beras melinjo dan $50 \%$ tepung beras ketan) yaitu 7,40 (suka), menyusul perlakuan B $(60 \%$ tepung melinjo dan $40 \%$ tepung beras ketan) yaitu 6,43 (agak suka), dan perlakuan A $(75 \%$ tepung beras melinjo dan $25 \%$ tepung 
beras ketan) yaitu 6,41 (agak suka), sedangkan perlakuan terendah yaitu $\mathrm{K}$ (0\% tepung melinjo dan 100\% tepung beras ketan) sebesar 5,77 (netral).

Tekstur dodol yang paling diminati oleh panelis yaitu yaitu pada perlakuan C $(50 \%$ tepung beras ketan dan $50 \%$ tepung melinjo), karna sesuai dengan penembahan tepung beras ketan.Sehingga dalam pembuatan dodol tepung beras ketan yang digunakan harus sesuai dengan tambahan tepung lainnya misalnya tepung melinjo.

\section{KESIMPULAN}

Simpulan yang dapat diperoleh dari hasil penelitian adalah sebagai berikut:

1. Terdapat pengaruh subtitusi tepung melinjo terhadap kandungan air, abu, lemak, protein dan karbohidrat, dimana kandungan kadar air terendah terlihat pada perlakuan $\mathrm{C}$, kandungan kadar abu terendah pada perlakuan $\mathrm{K}$, kadungan kadar lemak terendah pada perlakuan $\mathrm{K}$, kandungan protein tertinggi pada perlakuan $\mathrm{C}$ dan kandungan karbohidrat tertinggi pada perlakuan C.

2. Berdasarkan hasil uji organoleptik yang teridiri atas warna, rasa, aroma dan tekstur, subtitusi tepung melinjo terbaik yaitu pada perlakuan C $(50 \%$ tepung melinjo dan $50 \%$ tepung beras ketan)

\section{DAFTAR PUSTAKA}

Dewan Standarisasi Nasional. 1992. SNI No.01-2986-1992. Mengenai Syarat Mutu Dodol Buah. Jakarta.
Hardiansyah. 2000. Pengendalian Mutu dan Keamanan Pangan.Pergizi Pangan Indonesia. PAPTI, IPB dan Proyek $\mathrm{CHN}-3$, direktorat jenderal pendidikan tinggi, Jakarta.

Haryadi. 2006. Teknologi Pengolahan Beras.Gadjah Mada University Press.Yogyakarta.

Krisnatuti,\& Diah. 2004. Perencana Menu untuk Penderita Gangguan Asam Urat.Penebar Swadaya. Jakarta.

Matias,V. 2010. Denaturasi Protein. Makalah. Fakultas Teknologi Industri Pertanian Universitas Sahid. Jakarta.

Rampengan, V.J. Pontoh \& D.T. Sembel,. 1985. Dasar-Dasar Pengawasan Mutu Pangan. Ujung Pandang: Badan Kerjasama Perguruan Tinggi Negeri Indonesia Bagian Timur.

Satuhu, S., \& Sunarmani. 2004. Membuat Aneka Dodol Buah. Jakarta: Penebar

Soemaatmadja D. 1997. Pengawetan Pangan Di Indonesia. Bogor: IPB.

Syarief, R., \& A. Irawati.1988. Pengetahuan Bahan untuk Industri Pertanian.PT Mediyatama Sarana Perkasa. Jakarta

Tejasari. 2005. Nilai Gizi Pangan. Yogyakarta : Graha Ilmu. 
Winarno, F. G. 2004. Kimia Pangan dan

PustakaUtama, Jakarta.

Gizi. PT. Gramedia

Winarno, F.G. 2008.Kimia Pangan dan

Gizi edisi terbaru, Bogor M-brio press.

Yanti. L. 2002. Pengaruh Bahasa dan Jenis Ilustrasi Pada Buklet Terhadap Peningkatan

Pemahaman Petani Tentang

Pendayagunaan Melinjo (Kasus di

Desa Kasang Lopak Alai

Kecamatan Kumpeh Ulu

Kabupaten Muaro Jambi). Tesis

Program Pascasarjana.IPB. Bogor. 